\title{
A Template For Enhancing The Impact of The NATIONAL ACADEMY OF SCIENCES' REPORTING ON FORENSIC SCIENCE
}

\author{
Amelia Shooter* \\ Sarah L. Cooper**
}

\begin{abstract}
The National Academy of Sciences (NAS), established in 1863, is the United States' leading science and technology think-tank, with an active commitment to advising government. Over the last 150 years, the NAS has, both independently and in conjunction with the federal government, investigated and reported on various issues of importance, ranging from space exploration and biosecurity, to STEM education and immigration. Due to growing concerns about particular disciplines (and specifically their application in legal proceedings), one issue the NAS has reported on between 1992 and 2009 is forensic science. Specifically, the NAS has published six reports commenting on the status of forensic science evidence in the USA, namely DNA Technology in Forensic Science (1992), The Evaluation of Forensic DNA Evidence (1996), The Polygraph and Lie Detection (2003), Forensic Analysis: Weighing Bullet Lead Evidence (2004), Ballistic Imaging (2008), and Strengthening Forensic Science in the United States: A Path Forward (2009). The response of stakeholders (including from political, legal, and academic spheres) to these reports has varied, ranging from shifts in practice and full acknowledgement, to considerable struggles to effectuate systemic reform. Using the different experiences of two reports - Forensic Analysis: Weighing Bullet Lead Evidence (2004) and Strengthening Forensic Science in the United States: A Path Forward (2009) - as a vehicle, this article suggests how the $N A S$ can strengthen the impact of its forensic science reporting, and how stakeholders can better harness the expertise of the NAS.
\end{abstract}

\section{KEYWORDS}

National Academy of Sciences, Forensic Science, Reporting, Stakeholder Responses.

\section{CONTENTS}

INTRODUCTION 443

I: The National Academy of Sciences and Selected Reports on

ForensiC SCIENCE 444

A. Function and Research Portfolio of the NAS... 444

* PhD Candidate, Birmingham City University, School of Law.

** PhD, Reader, Birmingham City University, School of Law.

The authors would like to thank: participants at the Conference on American Politics, History and Law: A Cross-Disciplinary Dialogue sponsored by Birmingham City University's Centre for American Legal Studies, and The Monroe Centre at the University of Reading in July, 2018 for their feedback on Ms. Shooter's presentation that led to this article; Professor Lissa Griffin for her valuable feedback on an earlier draft; and Dr. Ilaria Di Gioia (and the wider BJALS team) for inviting us to contribute to this special edition. 
B. The CBLA Report and Strengthening: Report OVERVIEWS and STAKEHOLDER RESPONSES 445

i. Forensic Analysis: Weighing Bullet Lead Evidence (CBLA Report) 445

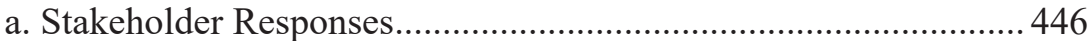

ii. Strengthening Forensic Science in the United States: A Path

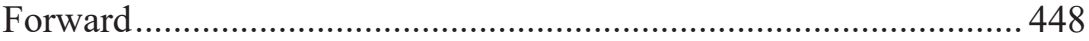

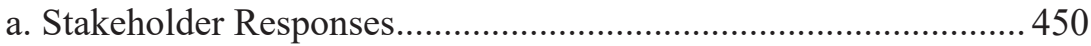

II: A Template For Future Reporting.............................................. 458

A. BUILDING ON EXISTING STAKEHOLDER ENGAGEMENT .................... 458

i. The NAS Reports as Referencing Tools ........................................ 458

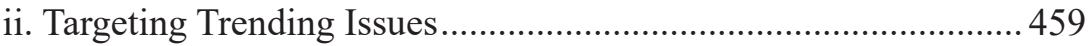

iii. State Level Engagement .............................................................. 460

iv. Taking Forward National Efforts .................................................. 460

B. Sensitivity to the FrameWorks Within Which Stakeholders

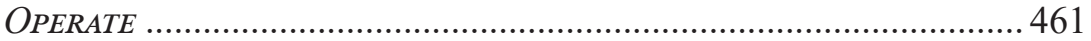

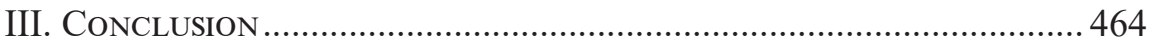




\section{INTRODUCTION}

DNA technology - when applied properly - provides the criminal justice system with a highly reliable identification method, which can be used to both convict and exonerate individuals. At the same time, however, this capacity of DNA technology undermines various forensic science identification techniques, including tool-mark, fingerprint, and bite-mark analysis, which the criminal justice system has routinely admitted as evidence for decades. ${ }^{1}$ Both the federal government and the National Academy of Sciences (NAS) - the United States' leading science and technology think-tank - have recognized this. In 1992 and 1996, following the introduction of DNA evidence into legal proceedings, ${ }^{2}$ the NAS, supported by federal funding, ${ }^{3}$ published two reports on the forensic use of DNA technology. In these reports, the NAS encouraged the criminal justice system to harness DNA technology - when conducted according to approved procedures - due to its evidence-based high reliability. ${ }^{4}$ Subsequently, federal bodies commissioned the NAS to report on the probative value of other, non-DNA forensic science techniques. ${ }^{5}$ This resulted in the publication of four reports: The Polygraph and Lie Detection (2003); ${ }^{6}$ Forensic Analysis: Weighing Bullet Lead Evidence (2004); ${ }^{7}$ Ballistic Imaging (2008); ${ }^{8}$ and Strengthening Forensic Science in the United States: A Path Forward (2009). ${ }^{9}$ Generally, these reports provide an examination of the reliability and validity of the relevant forensic science discipline(s), and include recommendations to the commissioning body. The response of stakeholders to these reports has varied, ranging from shifts in practice, and clear acknowledgements, to silence and considerable struggle to effectuate systemic forensic science reform.

This article, using the experiences of Forensic Analysis: Weighing Bullet Lead Evidence (CBLA Report) and Strengthening Forensic Science in the United States: $A$ Path Forward (Strengthening) as a vehicle, explores how the NAS can strengthen the impact of its forensic science reporting, and how stakeholders can better harness the expertise of the NAS in this context. These reports have been selected because of the clearly identifiable and diverse spectrum of responses they have drawn. Part I briefly outlines the function and research portfolio of the NAS and

1 See, in general, Paul C. Giannelli, Forensic Science: Under the Microscope 34 Оніо N. U. L. Rev. 315 (2008).

2 R v. Pitchfork [2009] EWCA (crim.) 963, [11] (Eng.); (Appeal outlines the first use of DNA evidence in 1987); Andrews v. State, 533 So.2d 841 (Fla. Dist. Ct. App. 1988).

3 Victor A. McKusick et Al., DNA Technology in Forensic Science (1992); James F. Crow et al., The Evaluation of Forensic DNA Evidence (1996).

$4 \quad I d$.

5 The report, The Polygraph and Lie Detection (2003) was commissioned by the United States Department of Energy, Forensic Analysis: Weighing Bullet Lead Evidence (2004) was commissioned by the FBI, Ballistic Imaging was commissioned by the National Institute of Justice, and Strengthening Forensic Science in the United States: A Path Forward (2009) was commissioned by Congress.

6 Stephen E. Feinberg, The Polygraph and Lie Detection (2003).

7 Kenneth O. MacFadden et al., Forensic Analysis: Weighing Bullet Lead EVIDENCE (2004).

8 Daniel L. Cork et al, Ballistic Imaging (2008).

9 Harry T. Edwards, Constantine Gatsonis et al., Strengthening Forensic Science in the United States: A Path Forward (2009). 
details the circumstances surrounding the publication of both the CBLA Report and Strengthening. This includes the findings of those reports and stakeholder responses to/associated with the reports, including those by the FBI, Department of Justice, Congress, the judiciary, state legislatures, and the White House. Part II identifies themes in the experiences of these reports, using them to shape a template that can - the authors suggest - be used to both strengthen the NAS' forensic science reporting, and enable stakeholders to better harness the expertise of the NAS. Part III concludes that the template will enable the NAS to take a lead role in increasing public confidence in the criminal justice system by facilitating cross-stakeholder collaboration, and by publicly normalizing and explaining the nature of scientific method, progress, findings, and uncertainty. This role aligns neatly with the NAS' unique history, function, and mission.

\section{I: The National Academy of Sciences and Selected REPORTS ON FORENSIC SCIENCE}

This section first outlines the history and function of the NAS. It then details the circumstances surrounding the publication of the CBLA Report and Strengthening, including the findings of those reports and the responses drawn from stakeholders.

\section{A. Function and Research Portfolio of the NAS}

In 1863, the NAS was established by President Lincoln to provide "independent, objective advice to the nation on matters related to science and technology." 10 The NAS is now considered to be the United States' premier scientific research center, with a statutory mandate to report on any scientific subject when called upon by the federal government. ${ }^{11}$ It is a "private, non-profit society of distinguished scholars," 12 with its members elected by their peers "for outstanding contributions to research." 13 The NAS' Mission Statement states it is "committed to furthering science in America", ${ }^{14}$ although its members are also notably "active contributors to the international scientific community." 15

Over the last 150 years, the NAS has generated a diverse portfolio of research that reflects the culture of scientific collaboration and inquiry. This portfolio includes reporting on matters of national security and welfare during World War I; ${ }^{16}$ exploring warfare technology in World War II ${ }^{17}$ mapping side

10 National Academy of Sciences, Mission, http://www.nasonline.org/about-nas/mission/ (last visited Dec. 9, 2018).

An Act to Incorporate the National Academy of Sciences, 36 U.S.C $\$ 251$ et seq. (1863).

National Academy of Sciences, supra note 10.

$I d$.

$I d$.

$I d$.

Albert L. Barrows, The Relationship of the National Research Council to Industrial Research, in Research: A National Resource: II: Industrial Research 365 (1940).

17 Id. at $396-97$. 
effects of atomic warfare and participating in international scientific exchanges ${ }^{18}$ during the Cold War; ${ }^{19}$ and, more recently, reporting on education, population growth, climate change, and forensic science..$^{20}$ During this time, the NAS has experienced evolving, challenging and productive relationships with various stakeholders, including the federal government, states, and scholars. ${ }^{21}$ This article focuses on stakeholder responses to two of the NAS' forensic science reports, namely the CBLA Report and Strengthening.

\section{B. THE CBLA REPORT AND STRENGTHENING: REPORT OVERVIEWS AND STAKEHOLDER RESPONSES}

\section{i. Forensic Analysis: Weighing Bullet Lead Evidence (CBLA Report)}

In the mid-twentieth century, Comparative Bullet-Lead Analysis (CBLA) was developed by the FBI as a tool to determine the source of bullet fragments found at crime scenes. ${ }^{22}$ The technique, exclusively used by the FBI, ${ }^{23}$ involves examiners comparing the chemical composition of a bullet fragment to suspect-related bullets. ${ }^{24}$ Typically, examiners analyze the ratio between seven chemical elements, and find a match if the chemical make-up of the two samples is sufficiently similar. ${ }^{25}$

In 2002, the FBI commissioned the NAS to produce "an impartial scientific assessment of the soundness of the scientific principles underlying $\mathrm{CBLA}^{26}$ to determine the optimum manner for conducting the examination and to establish scientifically valid conclusions." 27 This followed publication of concerns about

18 The government also made use of the NAS through a series of scientific exchanges between both the USSR and China. This proved to be valuable for international relations, with science maintaining dialogue between nations when political relations had broken down.

19 During the Cold War period, the NAS and NRC worked on a variety of research projects for the federal government, including oceanography, studies of pacific islands and improving international scientific dialogue and cooperation. As popular interest in subjects such as the effect of atomic warfare increased, the NAS was used by the federal government to map its effects.

20 See, e.g., George B. Kistiakowsky, Federal Support of Basic Research in Institutions of Higher Learning (1964); William D. McElroy, The Growth of World Population: Analysis of the Problems and Recommendations for Research and TRaining (1963).

21 For example, the report, Alan Leshner, Communicating Science Effectively (2017) was funded by a collection of private organizations, namely the Burroughs Wellcome Fund, the Rita Allen Foundation, the Gordon and Betty Moore Foundation, and the Hewlett Foundation.

22 MaCFADDEN ET AL, supra note 7, at 1.

23 William C. Thompson, Analyzing the Relevance and Admissibility of Bullet-Lead Evidence: Did the NRC Report Miss the Target, 46 JuRIMETRICS 65, 66 (2005-2006).

24 MACFADDEN ET AL, supra note 7, at 8, 19-20.

25 Id.

26 Throughout the report, CBLA evidence is referred to as CABL, or comparative analysis of bullet lead.

27 MacFadDEn et aL, supra note 7, at ix. 
the scientific basis for CBLA. ${ }^{28}$ This was the first time that CBLA evidence had received such scrutiny. ${ }^{29}$

In 2004, the NAS published its report Forensic Analysis: Weighing Bullet Lead Evidence. The report detailed the analytical method used by FBI examiners, ${ }^{30}$ and criticized much of the FBI's reporting procedures for incompleteness and lack of detail. ${ }^{31}$ Despite this, it recognized the FBI process as appropriate for determining the chemical composition of bullet lead. ${ }^{32}$ It discussed several methods for the statistical analysis of CBLA evidence, including error rates. ${ }^{33}$ The NAS found that the methods used by the FBI insufficiently appreciated the variability of bullets, both within the bullet population and differences in manufacturing processes. ${ }^{34}$ The report recommended to the FBI that the statistical procedures used to assess a match should employ standard deviations and be charted regularly. It also recommended that all examiners follow official FBI protocol(s) for CBLA, including properly maintaining documentation. ${ }^{35}$

The NAS also found that variations in manufacturing processes could undermine the probative value of CBLA evidence and potentially result in misleading comparisons. ${ }^{36}$ It recommended that further research be carried out to define different ranges of indistinguishable lead. ${ }^{37}$ The NAS also identified issues relating to the interpretation of CBLA evidence. ${ }^{38}$ This led them to recommend a more rigorous analysis process, ${ }^{39}$ and to caution the FBI that its analytical protocol needed revision to provide more clarity. ${ }^{40}$ The NAS, however, did not recommend that CBLA evidence be inadmissible in legal proceedings. ${ }^{41}$

\section{a. Stakeholder Responses}

This report primarily elicited responses from two stakeholder groups: the FBI and the judiciary.

28 Erik Randich, Wayne Duerfeldt, Wade McLendon, William Tobin, A Metallurgical View of the Interpretation of Bullet Lead Compositional Analysis ForensiC SCIENCE INTERNATIONAL 127, 174-191 (2002).

29 MACFADDEN ET AL, supra note 7, at 101.

30 Id. at 15.

31 Id. at 16 .

32 Id. at 23.

33 Id. at Chapter 3.

$34 \quad I d$, at 68 .

35 Id. at 68-70.

$36 \quad I d$. at 98.

$37 \quad I d$. at 106.

$38 \quad I d$. at 107.

$39 \quad I d$. at 107-08.

$40 \quad I d$. at 109-10.

$41 \quad I d$. at 107. 


\section{FBI Response}

Immediately after the report's publication, the FBI defended its use of CBLA, but expressed a willingness to undertake further research. ${ }^{42}$ However, in September 2005, the FBI published a press release stating that "after extensive study and consideration," ${ }^{43}$ it would "no longer conduct the examination of bullet lead." ${ }^{44}$ The FBI stated that it "firmly support[s] the scientific foundation" 45 of CBLA, but decided to discontinue CBLA due to costs associated with improvements, and that "neither scientists nor bullet manufacturers are able to definitely attest to the significance of an association.... in the course of a bullet lead examination. ${ }^{46}$

At the time of the FBI's decision, over 2,500 convictions had been secured using the CBLA technique. ${ }^{47}$ This attracted media attention (including from 60 Minutes and the Washington Post) ${ }^{48}$ which urged the FBI to review relevant convictions. ${ }^{49}$ Ultimately, the FBI partnered with the Innocence Project and Department of Justice to conduct such a review, ${ }^{50}$ stating that it was "expanding on a series of efforts initiated in 2002." ${ }^{51}$

\section{Judicial Response}

The CBLA Report has also been referenced in judicial decisions. Individuals have appealed convictions (with or without a FBI review letter) ${ }^{52}$ on the basis that the CBLA Report constitutes newly discovered evidence.

Newly discovered evidence claims "usually involve some combination of showings that the new evidence could not have been discovered prior to trial with the exercise of reasonable diligence; that the evidence is relevant and not cumulative or merely impeaching; and that the new evidence creates a sufficient probability of a different result at a new trial." ${ }^{53}$ Petitioners have used this mechanism to argue that the CBLA Report is new evidence capable of undermining the trial result.

42 Charles Piller, Report Finds Flaws in FBI Bullet Analysis, LA Times, $2004 \mathrm{http} / /$ articles. latimes.com/2004/feb/11/science/sci-bullet11 (last visited Dec. 9, 2018).

43 FBI National Press Office, FBI Laboratory Announces Discontinuation of Bullet Lead Examinations (Sept. 1, 2005) https://archives.fbi.gov/archives/news/pressrel/pressreleases/fbi-laboratory-announces-discontinuation-of-bullet-lead-examinations.

44 Id.

45 Id.

46 Id.

$47 \quad I d$.

48 See CBS, Evidence of Injustice, YouTube (Sept. 14, 2008) https://www.youtube.com/ watch? $\mathrm{v}=\mathrm{H} 4 \mathrm{~g} 62 \mathrm{cpRz} 7 \mathrm{M}$ (last visited Dec. 9, 2018).

49 CBS News, Evidence of Injustice, 2007 https://www.cbsnews.com/news/evidence-ofinjustice/ (last visited Dec. 9, 2018).

50 FBI National Press Office, FBI Laboratory to Increase Outreach in Bullet Lead Cases (Nov. 17, 2007) https://archives.fbi.gov/archives/news/pressrel/press-releases/fbilaboratory-to-increase-outreach-in-bullet-lead-cases.

$51 \quad$ Id.

52 The FBI, as part of a review of CBLA cases, sent letters to individuals affected to make them aware of the limitations of the evidence.

53 Keith A. Findley, Defining Innocence, 74 Alb. L. Rev. 1157, 1197 (2010). 
Some petitioners have succeeded in cases where CBLA evidence was the primary evidence against the petitioner. For example, in Ward v. State, the Court of Special Appeals of Maryland held that various pieces of evidence coming to light after trial (including the CBLA Report) constituted newly discovered evidence, and vacated the petitioner's conviction. ${ }^{54}$ Similarly, in Murphy v. State the court also agreed that the CBLA Report constituted newly discovered evidence, as the report's findings were not discoverable at trial, leading the court to reverse the conviction. ${ }^{55}$

By contrast, other courts have determined that the CBLA Report is not newly discovered evidence. This has been for various reasons, including that CBLA's loss of 'general acceptance' neither affects previous decisions in the case, ${ }^{56}$ nor renders trials fundamentally unfair. ${ }^{57}$ Another reason is the court's conclusion that, in the individual case, the limitations of CBLA had been brought to the jury's attention during cross-examination. ${ }^{58}$ In More v. State, for example, the Supreme Court of Iowa recognized the report as a "blockbuster" constituting newly discovered evidence, ${ }^{59}$ but did not find fundamental unfairness in the trial, as the defendant did not suffer actual prejudice. ${ }^{60}$ Similarly, the Kentucky Supreme Court in St Clair v. Commonwealth, determined that although CBLA evidence is no longer admissible, it does not go so far as to justify a new trial, as the CBLA expert conceded that the evidence was not infallible. ${ }^{61}$

Another identifiable approach in rejecting newly discovered evidence claims emerges where a conviction was supported by other, non-CBLA evidence. In such cases, judges have reasoned that, due to the presence of other inculpatory evidence, the exclusion or undermining of CBLA evidence would not have resulted in a different trial outcome. For example, the Supreme Court of Minnesota dismissed the petitioner's claim in Gassler v. State, deciding that the additional evidence presented to the jury at trial meant that removing CBLA evidence would have no effect on the jury's decision. ${ }^{62}$

\section{ii. Strengthening Forensic Science in the United States: A Path Forward}

In 2005, Congress commissioned the NAS to report on the general status of forensic science after recognizing that "significant improvements are needed in forensic science." ${ }^{63}$ The report aimed to "chart an agenda for progress in the forensic science community and its scientific disciplines." 64 To do this, the NAS engaged in a comprehensive consultation with stakeholders and experts. ${ }^{65}$ The evidence received

\footnotetext{
Ward v. State, 221 Md. App. 146 (Md. Ct. Spec. App. 2015).

Murphy v. State, 24 So.3d 1220 (Fla. Dist. Ct. App. 2009).

Commonwealth v. Kretchmar, 971 A.2d 1249 (Pa. 2009).

Gonzales v. Thaler, 2012 WL 5462682 (S.D. Tex. Oct 23, 2012).

United States v. Higgs, 663 F.3d 726 (D. Md. 2010).

More v. State, 880 N.W.2d 487, 509 (Iowa 2016).

Id. at 512-13.

St Clair v. Commonwealth, 451 S.W.3d 597 (Ky. 2014).

Gassler v. State, 787 N.W.2d 575 (Minn. 2010).

EDWARDS ET AL, supra note 9, at xix.

$I d$. at xix.

$I d$. at 2 .
} 
by the NAS was "detailed, complex, and sometimes controversial." ${ }^{66}$ In its report, therefore, the NAS decided to "reach a consensus on the most important issues," and offer specific recommendations in relation to them. ${ }^{67}$

Strengthening was published in 2009, reporting on forensics in general and on individual forensic science disciplines in particular. The overall finding of the report was that the forensic science sector was fragmented and under-resourced, ${ }^{68}$ which limited its potential to effectively service stakeholders. ${ }^{69}$ The NAS recommended that Congress create an independent oversight body to monitor the implementation of the report's recommendations,$^{70}$ which were designed to improve adherence to standards and provide forensic science education. ${ }^{71}$

With regards to specific disciplines, the report evaluated each discipline's adherence to fundamental scientific principles. $^{72}$ This included: biological evidence ${ }^{73}$ drug and controlled substance analysis $;{ }^{74}$ friction ridge analysis (fingerprints) ${ }^{75}$ other pattern and impression evidence, ${ }^{76}$ tool-mark and firearms identification evidence; ${ }^{77}$ microscopic hair evidence $;{ }^{78}$ fiber evidence $;{ }^{79}$ document examination, ${ }^{80}$ paint and coatings evidence, ${ }^{81}$ explosives evidence and fire debris, ${ }^{82}$

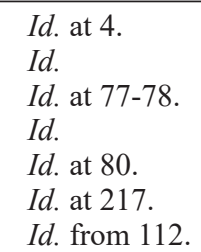

73 The report examines blood stain, and other biological fluid evidence, concluding that nuclear DNA analysis is the most reliable way of attributing fluids to individuals, but other DNA analysis methods are available. As DNA developed through scientific methods, analysis is highly reliable. Id. at 128-133.

74 The report expresses concerns that appropriate standards and recommendations are not followed, as they cover a range of drugs - it is the analyst's responsibility to decide the appropriate testing method. This is problematic as drug analysis reports are often inadequate. Id. at 133-36.

75 In acknowledging the utility of fingerprint analysis, the report refuted claims of a zero error rate. They found limited research supporting reliability of analysis techniques and individualization of prints, recommending further research. Id. at 136-45.

76 The report found that experts find it difficult to avoid bias, and that the experience-reliant nature of impression matching rendered the imposition of standards difficult. Further research to understand the rarity of characteristics was recommended. Id. at 145-50.

77 In concluding, the report determined that not enough is known about tool-mark variability, meaning that it is impossible to set a confidence level. They also showed concern about a lack of defined analysis process and difficulties with experts' qualitative reasoning. Id. at 150-55.

78 The report did not find any scientifically accepted statistics about frequency distribution of hair characteristics. Id. at 60. It also commented that "testimony linking microscopic hair analysis with particular defendants is highly unreliable." Id. at 155-161.

79 No studies were found supporting methods of matching hair fibers, leaving a determination of a match ambiguous as to its probative value. Id. at 161-63.

80 The report concluded that the scientific basis of document examination needs strengthening, as limited research has been carried out. Id. at 163-67.

81 While based on a solid foundation of chemistry, the report expressed concerns about the lack of standard practices for determining a match of two samples. Id. at 167-70.

82 The report supported the chemistry-based foundations of explosives evidence, but found 
forensic odontology (bite-mark impressions) ${ }^{83}$ bloodstain pattern analysis ${ }^{84}$ and digital and multimedia analysis. ${ }^{85}$ The NAS found that these techniques varied in their reliability and underpinning research, ${ }^{86}$ and that several techniques "do not contribute as much to criminal justice as they could." ${ }^{87}$ Ultimately, the NAS concluded that "with the exception of nuclear DNA analysis... no forensic method has been rigorously shown to have the capacity to consistently, and with a high degree of certainty, demonstrate a connection between evidence and a specific individual or source." ${ }^{88}$ This was hailed as a landmark and unprecedented conclusion. ${ }^{89}$

Although the NAS did not make prescriptive comments on the admissibility of forensic techniques, it discussed what it saw as inadequacies in legal admissibility standards. ${ }^{90}$ Its findings were particularly critical of judicial decision-making under Daubert, ${ }^{91}$ which requires judges - as part of their gate-keeping role - to consider error-rates, professional standards, general acceptance, testability, and peer review of disciplines to determine the admissibility of expert evidence. The NAS stated, that "the present situation... is seriously wanting"92 and that "Daubert has done little to improve the use of forensic science evidence in criminal cases. ${ }^{" 93}$

\section{a. Stakeholder Responses}

Ten years post-publication, a significant body of literature discussing Strengthening exists. ${ }^{94}$ Most recently, co-chairs of the committee that authored Strengthening, Harry T. Edwards and Constantine Gatsonis, were awarded the Innocence Network's 2018 Champion of Justice Award. The Innocence Project thanked the committee for the report, stating it "has truly transformed the state of forensic science and the involvement of the research community in service of criminal justice reform. $"{ }^{95}$ Over the last decade, the critical messages of Strengthening

very little research into burn patterns, leaving expert opinions unsupported. Id. at 17073.

83 The reliability of bite mark evidence was refuted, with the report rejecting the methods used by analysts to identify individuals based on dental impressions. The report noted that no thorough studies have been carried out supporting the use of this technique. Id. at $173-76$.

84 Some aspects of bloodstain pattern analysis are supported by studies, but the technique is resource intensive. $I d$. at 177-179.

85 The report acknowledges the emerging nature of this field, acknowledging its potential to collect vast amounts of information. The report noted that greater training amongst law enforcement is needed. $I d$. at 179-82. EDWARDS ET AL, supra note 9, at 182.

87 Id. at 183.

88 Id. at 7.

89 D. Michael Risinger, The NAS/NRC Report on Forensic Science: A Path Forward Fraught with Pitfalls, 2010 UtaH L. Rev. 225, 225-26 (2010).

90 EDWARDS ET AL, supra note 9, at 86-95.

91 Id. at 107-09.

$92 \quad I d$. at 110.

93 Id. at 106.

94 A literature review searching Strengthening Forensic Science in the United States: A Path Forward has produced 391 results. This was carried out in 2018. This catalogue is on file with the authors.

95 The National Academies of Sciences, Engineering and Medicine, Co-Chairs of 
have attracted various stakeholder responses, including from Congress, state legislatures, the judiciary, the Department of Justice, FBI, and White House. These are summarized below.

\section{Congress}

The report's recommendations, including the creation of the oversight bodynominally called the National Institute of Forensic Science-were naturally directed towards Congress. In 2009, the House of Representatives Committee on Science and Technology discussed how Strengthening's findings and recommendations would relate to the work of the National Institute of Standards and Technology. ${ }^{96}$ The Senate Judiciary Committee discussed the report's findings in the light of a 2009 United States Supreme Court decision-Melendez-Diaz v. Massachusetts. ${ }^{97}$ In that case the Court had, citing Strengthening, commented that forensic science was subject to "serious deficiencies." 98 Noting this comment, the Senate Judiciary Committee took evidence from various stakeholders, including the Innocence Project, ${ }^{99}$ police, ${ }^{100}$ academics, ${ }^{101}$ and attorneys. ${ }^{102}$ The discussion ultimately identified concerns about the resources required to implement reform, with post-hearing submissions highlighting the need for financial and organizational re-structuring of the forensic science sector. ${ }^{103}$ This prompted discussion about the feasibility of reforms, ${ }^{104}$ and to date Congressional efforts to introduce comprehensive legislative reform have faced significant challenges. ${ }^{105}$ Despite this, existing DNA-based initiatives have continued to receive funding. For example, the Debbie Smith Act was reauthorized in 2014, providing \$968 million over the 2015-2019 period to assist the Department of Justice in clearing DNA backlogs. ${ }^{106}$ With the cost of creating and maintaining forensic science standards being a decisive factor, Congress' ability to enact meaningful systemic reform has been questioned. ${ }^{107}$

\section{State Legislatures}

Prior to Strengthening, numerous states had established bodies with the capacity to provide forensic science oversight. ${ }^{108}$ There is evidence to suggest that the messages

Forensic Science Report Honored by Innocence Network, Apr. 12, 2019, http://www8. nationalacademies.org/onpinews/newsitem. aspx?RecordID $=4122019$.

96 S. Rep. No. 111-8 (2009).

97 Melendez-Diaz v. Massachusetts, 557 U.S. 305 (2009).

98 Id.

99 S. Rep. No. 111-554, at 8 (2009).

$100 I d$. at 10.

101 Id. at 12.

102 Id. from 14.

103 Id. at 38-39.

104 Id. at 38.

105 See, e.g., Forensic Science and Standards Act of 2012, S. 3378, 112 ${ }^{\text {th }}$ Cong. (2012).

106 Debbie Smith Reauthorization Act of 2014, H.R. 4323, $113^{\text {th }}$ Cong., at 5 (2014).

107 See, e.g., Eric Maloney, Two More Problems and Too Little Money: Can Congress Truly Reform Forensic Science, 14 Minn. J. L. ScI. \& Tech. 923 (2013).

108 For a summary of the New York Commission on Forensic Science, see Paul C. Giannelli, Regulating DNA Laboratories: The New Gold Standard? 69 N.Y.U AnN. SuRv. Am. L. 
within Strengthening have shaped the work of some of these bodies. For example, Texas's judicial commission that investigates public complaints about forensic science, has embraced Strengthening's findings as being "at the forefront of the national dialogue on efforts to improve forensic science." 109 It has also spent time discussing challenges and improvements based on the report's findings. ${ }^{110}$ In North Carolina, Strengthening, coupled with the findings of the North Carolina Innocence Inquiry Commission about forensic science practices, ${ }^{111}$ has influenced the state legislature to reform forensic science services. ${ }^{112}$ Reforms include renaming the State Bureau of Investigations to formally separate it from law enforcement, following Strengthening's recommendations, ${ }^{113}$ and creating a review board to oversee the work of laboratory employees. ${ }^{114}$

\section{Judicial Decisions}

Judicial responses to Strengthening are considered in two categories. First, the Supreme Court's decision in Melendez-Diaz. ${ }^{115}$ Second, the general approaches of lower courts to Strengthening.

Shortly after Strengthening's publication, the United States Supreme Court in Melendez-Diaz v. Massachusetts relied on the report to acknowledge that "the forensic science system... has serious problems that can only be addressed by a national commitment to overhaul the current structure." 116 In that case, the court clarified that forensic science analysts are witnesses under the Confrontation Clause, and are therefore required to testify in court and be subject to cross-examination. ${ }^{117}$ Although described as a "straightforward application" of precedent by Justice Scalia, ${ }^{118}$ the decision has subsequently been cited to reverse proceedings where live witnesses have not appeared. ${ }^{119}$

617, 628 (2013-2014).

109 Texas Forensic Science Commission, Annual Report FY2011 - Justice Through SCIENCE, 25 (2012) http://www.txcourts.gov/media/1440349/fsc-annual-report-fy2012. pdf.

110 Texas Forensic Science Commission, Second Annual Report May 2012-November 2013 - Justice Through Science, 19 (2013) http://www.txcourts.gov/media/1440350/ fsc-annual-report-fy2013.pdf.

111 The North Carolina Innocence Inquiry Commission, About, http://innocencecommissionnc.gov/about/ (last visited April 20, 2019).

112 Kavita Pillai, Another Competitive Enterprise: A Balanced Private-Public Solution to North Carolina's Forensic Science Program 90 N. C. L. Rev. 253, 257 (2011-2012).

113 EDWARDS ET AL, supra note 9, at 23.

114 Pillai, supra note 112, at 258.

115 Melendez-Diaz v. Massachusetts, 557 U.S. 305 (2009).

$116 \quad I d$. at 319.

117 Id.

$118 \quad I d$. at 312.

119 See e.g., Commonwealth v. Vasquez, 456 Mass. 350 (Mass. 2010); State v. Ward, 364 N.C. 133 (N.C. 2010). 
A review of lower court case law between 2009 and 2018 shows that Strengthening has been cited across over 200 appeal judgments. ${ }^{120}$ Generally, this cohort of cases shows petitioners using Strengthening to support a claim that - due to unreliability - particular forensic science evidence is not/should not have been admissible; and that Strengthening constitutes 'newly discovered evidence' capable of undermining previous outcomes. In responding to these claims, the authors have identified, in particular, five general approaches to Strengthening. These approaches are outlined below.

\section{Silence}

Some courts have simply been silent about the report. There are several judgments where the report has been considered in the dissent, but is absent in the majority decision. For example, the majority judgment in Commonwealth v. Treiber is silent with regards to Strengthening, but the dissenting opinion highlights the need to use Strengthening to address limitations of forensic science evidence. ${ }^{121}$ The dissenting opinion in Ex Parte Robbins also made reference to Strengthening, in the absence of its mention in the majority judgment. The report was used to demonstrate the disconnect between, on one hand, the scientific method, and on the other, legal process. ${ }^{122}$

\section{Strengthening as a Referencing Tool}

Courts have used Strengthening as a referencing tool. For instance, Strengthening has been cited to provide an authoritative explanation of forensic science techniques, including a definition of tool-mark identification techniques; ${ }^{123}$ an explanation of the ACE-V method used to compare fingerprint evidence; ${ }^{124}$ and to explain the roles and to explain the roles of both the medical ${ }^{125}$ and autopsy examiner. ${ }^{126}$

\section{Strengthening is Insufficient to Undermine Regular Legal Process}

Some courts have acknowledged the concerns raised in Strengthening, but have determined that those concerns do not fatally undermine relevant evidence because that evidence has been subject to regular legal procedures aimed at evaluating the evidence. For instance, courts have found that the challenged forensic evidence

120 The author has undertaken a comprehensive review of cases as part of a wider study examining judicial engagement with the six forensic science NAS reports. Out of 644 cases identified, 218 referred to Strengthening Forensic Science in the United States: A Path Forward. This data is on file with the authors.

121 See Commonwealth v. Treiber, 632 Pa. 449 (Pa. 2015).

122 Ex Parte Robbins, 360 S.W.3d 446, 470 (Tex. App. 2011).

123 See United States v. Otero, 849 F.Supp.2d 425 (D. N.J. 2012).

124 See United States v. Herrera, 704 F.3d 480 ( $7^{\text {th }}$ Cir. 2013) and People v. Luna 989 N.E.2d 655 (Ill.App.Ct. 2013).

125 See State v. Jaramillo, 272 P.3d 682 (N.M. Ct. App. 2011).

126 See Rosario v. State, 175 So.3d 843 (Fla. Dist Ct. App. 2015). 
was properly considered by the trial judge, ${ }^{127}$ lawyers, and/or jury. ${ }^{128}$ In United States v. Herrera, for example, the appeal court discussed the judicial approach to fingerprint evidence. In concluding that the judge had properly approached the evidence, and that the evidence "doesn't have to be infallible to be probative," 29 the petitioner's claim that Strengthening undermined fingerprint evidence was dismissed. In Commonwealth v. Gambora, the court undertook a lengthy discussion on the questions raised by Strengthening about the limitations of fingerprint individualization. They found Strengthening's findings to be "important, and deserv[ing] [of] consideration," 130 but ultimately held that defense counsel hadin the process of cross-examination-emphasized the lack of individualization sufficiently. ${ }^{131}$ Similarly, in State v. Thomas, the appellant argued that Strengthening undermined the firearm evidence presented during his trial. ${ }^{132}$ The court, however, determined that as there had been no plain error; the report's findings contributed towards the weight of the evidence, not admissibility. ${ }^{133}$

\section{Strengthening as Support for Limitations on Expert Testimony}

Strengthening has seemingly informed judicial decisions to limit expert firearms testimony. ${ }^{134}$ For instance, in United States $v$. Ashburn, the expert's testimony was curtailed to "a reasonable degree of certainty in the ballistics field," as opposed to "a "practical impossibility" that any other firearm fired the cartridges in question." ${ }^{135}$ In making this decision, the court reviewed firearms identification, weighing AFTE practices and guidelines against the findings and recommendations of Strengthening. Following a review of Strengthening, the judge in United States v. Taylor also limited the expert from concluding that "there is a match to the exclusion... of all other guns."136

\section{Strengthening as 'Newly Discovered Evidence'}

Courts have routinely dismissed newly discovered evidence petitions that claim Strengthening is new evidence. Judges have reasoned that Strengthening does not meet the requirements of newly discovered evidence because it is merely a "newly

127 See, e.g., United States v. Herrera, 704 F.3d 480, 486 ( $7^{\text {th }}$ Cir. 2013); People v. Jones, 2013 WL 5397389 (Cal. Ct. App. Sept. 26, 2013); People v. Morris, 997 N.E.2d 847 (Ill. App. Ct. 2013).

128 See, e.g., State v. Thomas, 2016 WL 7799279 (Tenn. Ct. App. March 28, 2016); State v. Romero, 236 Ariz. 451 (Ariz. Ct. App. 2014).

129 United States v. Herrera, 704 F.3d 480 ( $7^{\text {th }}$ Cir. 2013).

130 Commonwealth v. Gambora, 457 Mass. 715, 727-728 (Mass. 2010).

131 Id.

132 State v. Thomas, 2016 WL 779929, 13 (Tenn. Ct. App. March, 28 2016).

133 Id. at 16.

134 A noticeable pattern in judicial decisions limiting the extent of firearms testimony is evident; see, in general, Sarah L. Cooper \& Páraic Scanlon, Juror Assessment of Certainty About Firearms Identification Evidence, 40 UALR L. REv. 95 (2017).

135 United States v. Ashburn, 88 F.Supp.3d 239 (E.D.N.Y. 2015); also see United States v. Taylor, 663 F.Supp.2d 1170 (D.N.M 2009).

136 United States v. Taylor, id. at 1180. 


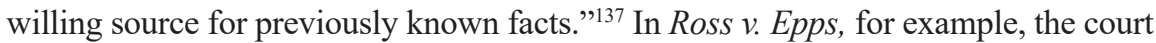
found Strengthening did not provide any new evidence contradicting what was said at trial i.e., did not have outcome changing capacity. ${ }^{138}$ This approach has been taken by a number of court decisions examining different forensic science techniques. ${ }^{139}$

However, Strengthening has seemingly been influential in successful newly discovered evidence claims relating to microscopic hair analysis. In Commonwealth v. Edmiston, ${ }^{140}$ Strengthening was used as authority for the notion that there is "no scientific support for the use of microscopic hair analysis." 141 This approach was cited in Commonwealth v. Chmiel, in which Strengthening was referred to as the "tipping point" in rejecting hair analysis evidence. ${ }^{142}$ Furthermore, in Commonwealth v. Perrot, the court acknowledged that Strengthening, (combined with the FBI's review of relevant hair cases) formed a "new consensus on the limitations and nature of hair analysis [that] constitutes newly available evidence."143

\section{FBI Response}

Notwithstanding the FBI's review of microscopic hair analysis cases, the FBI has been criticized for its reluctance to modify practice following the publication of Strengthening. ${ }^{144}$ In particular, the FBI's public objection to Strengthening's finding that the validity of fingerprinting is unknown, ${ }^{145}$ has led to questions about the FBI's commitment to forensic science reform. ${ }^{146}$ For instance, Cole has criticized the FBI for both creating barriers to proficiency testing, ${ }^{147}$ and "grandfathering" longstanding forensic evidence. ${ }^{148}$ This latter practice, it has been suggested, has led to forensic science disciplines with long-term admissibility records being sheltered from scrutiny ${ }^{149}$ Giannelli has criticized the actions of the FBI, arguing that their "shaping the research agenda, limiting access to data, attacking experts..., and "spinning" negative reports" 150 is preventing Strengthening from having a meaningful impact.

Commonwealth v. Riddick, 2017 WL 6568212 (Pa. Super. Ct. 2017 Dec. 26, 2017).

38 Ross v. Epps, 2015 WL 5772196 (N.D. Miss. Sept 30, 2015).

139 See, e.g., Johnston v. State, 27 So.3d 11 (Fla. 2010) (Fingerprints - Strengthening); Foster v. State, 132 So.3d 40 (Fla. 2013) (Ballistics Evidence - Strengthening); Enderle v. State, 847 N.W.2d 235 (Iowa Ct. App 2014) (Fingerprints - Strengthening).

140 This petition was not successful due to being time-barred.

141 Commonwealth v. Edmiston, 65 A.3d 339, 351 (Pa. 2013).

142 Commonwealth v. Chmiel, 173 A.3d 617 (Pa. 2017).

143 See, e.g., Commonwealth v. Perrot, 2016 WL 380123 (Mass. App. Ct. Jan. 26, 2016).

144 Jonathan J. Koehler, Forensic Science Reform in the 21st Century: A Major Conference, a Blockbuster Report and Reasons to be Pessimistic, 9 Law, Prob. \& Risk 1, 4 (2010).

145 Simon A. Cole, Who Speaks for Science? A Response to the National Academy of Sciences Report on Forensic Science 9 Law, Prob. \& Risk 25, 37 (2010).

146 See Koehler, supra note 144, at 4.

147 Simon A. Cole, Grandfathering Evidence: Fingerprint Admissibility Rulings from Jennings to Llera Plaza and Back Again, 41 Am. Crim. L. Rev. 1189 (2004).

148 Id.

149 See, e.g., Herbert B. Dixon, Forensic Science Under the Spotlight, 48 Judges J. 36, 37-38 (2009); Mark S. Bridin, Behavioral Science Evidence in the Age of Daubert: Reflections of a Skeptic, 73 U. Cin. L. Rev. 867, 892-893 (2004).

150 Paul C. Giannelli, Daubert and Forensic Science: The Pitfalls of Law Enforcement Control of Scientific Research, 2011 U. ILL. L. Rev. 53, 90 (2011). 


\section{Department of Justice}

Strengthening criticized the Department of Justice (DOJ) for neglecting its role in improving forensic science, finding that "the research funding strategies of [the] DOJ have not adequately served the broad needs of the forensic science community." 151 The DOJ has been identified as a stakeholder capable of facilitating meaningful reform, ${ }^{152}$ but its desire to make use of this capacity has been questioned. Giannelli, for example, has accused the DOJ of "sabotaging efforts" 153 to conduct research, and Lander has confronted the DOJ's resistance to the need for empirical support for evidence. ${ }^{154}$ Barkow, however, has reasoned that conflicts exist between the DOJ's prosecuting role and the need for further research, and "when they have, prosecution interests have won out." 155

That said, the DOJ did act when it became clear that a National Institute of Forensic Science would not materialize through an act of Congress. ${ }^{156}$ In 2013, the DOJ collaborated with the National Institute of Standards and Technology to create the National Commission on Forensic Science (NCFS) ${ }^{157}$ The NCFS was vested in the DOJ ${ }^{158}$ but designed to fulfil Strengthening's oversight recommendations. ${ }^{159}$ The creation of the NCFS was welcomed, ${ }^{160}$ and between 2013 and 2017 it engaged in a research and reform agenda. ${ }^{161}$ On the expiration of its four-year charter, however, the NCFS was disbanded. ${ }^{162}$ The NCFS reported that further work was necessary to enact reforms. ${ }^{163}$ The NCFS's short tenure revived concerns about the DOJ's commitment to improving forensic science. Former NCFS member, Professor Jules Epstein, has evaluated the work of the NCFS, noting that political considerations precluded the commission from truly advancing forensic science, calling efforts "evocative of Alice in Wonderland ... and not conducive to placing scientific

151 EDWARDS ET AL, supra note 9, at 18.

152 Giannelli, supra 150, at 90.

153 Id.

154 The Philip D. Reed Lecture Series Advisory Committee On Evidence Rules: Symposium on Forensic Expert Testimony, Daubert, and Rule 702, 86 Fordham L. Rev. 1463, 1521-22 (2018).

155 Rachel E. Barkow, Prosecutorial Administration: Prosecutor Bias and the Department of Justice, 99 VA. L. Rev. 271, 306-07 (2013).

156 This was despite wide support from academics. See, e.g., Margaret A. Berger, Evolving Trends in Forensic Science, 6 Tenn. J. L. \& Pol'y 147 (2010).

157 National Commission on Forensic Science, Reflecting Back: Looking Toward THE Future, 1 (2017).

158 NIST, National Commission on Forensic Science, https://www.nist.gov/topics/forensicscience/national-commission-forensic-science (last visited Dec. 9, 2018).

159 National Commission on Forensic SCience, supra note 157, at 3.

160 Jonathan J. Koehler, John B. Meixner, Jr., An Empirical Research Agenda for the Forensic Sciences, 106 J. CRIM. L. \& Criminology 1, 8 (2016).

161 During its four-year tenure, the NCFS adopted 43 work products, requiring action from the Attorney General, 20 recommendation documents and 23 views documents. These have either explored foundational documents designed to strengthen the reliability and validity of forensic science evidence, operational work products, and relational work products. See, supra note 158.

162 The United States Department of Justice Archives, National Commission on Forensic Science, https://www.justice.gov/archives/ncfs (last visited Dec. 9, 2018).

163 National Commission on Forensic Science, supra note 157. 
validity first." 164 The need for an oversight body being able to independently navigate its mission is evidently important.

\section{The White House}

As part of broader attempts to improve criminal justice, the Obama Administration reviewed Strengthening within a 2016 report by the President's Council of Advisors on Science and Technology (PCAST). ${ }^{165}$ The PCAST report supported Strengthening's findings, ${ }^{166}$ but went beyond Strengthening by recommending that judges limit the admissibility of particular disciplines. ${ }^{167}$ Despite this, the report's findings were dismissed by the $\mathrm{FBI}^{168}$ and the DOJ, ${ }^{169}$ and rejected completely by the AFTE (Association of Firearm and Tool Mark Examiners), who described the report as "lack[ing] in adequate investigation and understanding." 170 The PCAST report has been referenced alongside Strengthening by some courts. For example, in United States v. Bonds, both reports were referenced to argue that fingerprint evidence is not sufficiently reliable to be admitted into evidence. ${ }^{171}$ While the court acknowledged PCAST's findings, the court determined that these concerns should go to the weight of evidence, not admissibility. ${ }^{172}$ This decision has since been followed by subsequent courts, which have used Bonds to determine that "the PCAST report presents only advisory recommendations concerning validity," 173 and that the issue remains one of weight, and therefore a matter for the jury to determine.

164 Jules Epstein, The National Commission on Forensic Science: Impactful or Ineffectual?, 48 Seton Hall L. Rev. 743, 771 (2018).

165 Executive Office of the President, President's Council of Advisors on Science and Technology, Forensic Science in Criminal Courts: Ensuring Scientific Validity of Feature Comparison Methods (2016).

166 See, e.g., Geoffrey Stewart Morrison \& William C. Thompson, Assessing the Admissibility of a New Generation of Forensic Voice Comparison Testimony, 18 Colum. SCI. \& TeCH. L. Rev. 326, 334 (2017); Eric S. Lander, The Philip D. Reed Lecture Series Advisory Committee on Evidence Rules: Fixing Rule 702: The PCAST Report and Steps to Ensure the Reliability of Forensic Feature-Comparison Methods in the Criminal Courts, 86 FordHAM L. REv. 1661 (2018).

167 Executive Office of the President, supra note 165, at 142-45.

168 FBI, Comments on: President's Council of Advisors on Science and Technology RePORT to THE President Forensic Science in the Criminal Courts: Ensuring Scientific Validity of Pattern Comparison Methods, Sept. 20, 2016 https://pceinc.org/wp-content/ uploads/2016/10/20160920-Response-to-PCAST-Report-FBI-.pdf.

169 Gary Fields, White House Advisory Council Report is Critical of Forensics Used in Criminal Trials, Wall Street Journal, Sept. 20, 2016.

170 Association of Firearm and Tool Mark Examiners, Response to PCAST Report on Forensic Science, Oct. 31, 2016 https://afte.org/uploads/documents/AFTE_PCAST_ Response.pdf.

171 United States v. Bonds, 2017 WL 4511061 (N. D. Ill. 2017).

172 Id.

173 United States v. Pitts, 2018 WL 1116550, 5 (E.D.N.Y. 2018). See also, People v. Perez, 2019 WL 2537688 (Cal. Ct. App. 2019); State v DeJesus, 436 P.3d 834 (Wash. Ct. App. 2019). 


\section{II: A Template For Future Reporting}

The various stakeholder responses to both the CBLA Report and Strengthening are informative. They provide guidance on what messages stakeholders have received and/or acted on from the two reports, but also what issues seemingly limit stakeholders in responding comprehensively to concerns raised by the reports. Based on the experiences of the CBLA Report and Strengthening, Part II presents a template i.e., ideas for the NAS to consider when reporting on forensic science. This template is suggested with a view to both enhancing the NAS' impact when reporting, and enabling stakeholders to better harness the expertise of the NAS. The template has two parts. The first part-outlined in sub-section (A) - encourages the NAS to build on existing stakeholder engagement. The second part-outlined in sub-section (B) - encourages the NAS to be more expressly sensitive to the frameworks/cultures within which stakeholders operate.

\section{A. BUILDING ON EXISTING STAKEHOLDER ENGAGEMENT}

Part I outlined how the selected NAS reports have attracted stakeholder engagement. This is true beyond these two specific reports. ${ }^{174}$ Reflecting on existing traction, this subsection suggests four areas where the NAS could target its activity.

\section{i. The NAS Reports as Referencing Tools}

Case law consistently demonstrates that the NAS' reports on forensic science are used by judges as a reference tool. As pointed out in Part I, this is true of Strengthening. ${ }^{175}$ The $C B L A$ Report has also been used by judges as a referencing tool, such as in United States v. Berry, where the CBLA Report was used to consider how CBLA matches are declared, and an excerpt from the report was quoted to provide information about variations in reliability of CBLA, as manufacturing processes are not taken into account during analysis. ${ }^{176}$ This is also the case beyond these two reports. For example, judges have used DNA Technology in Forensic Science and The Evaluation of Forensic DNA Evidence as authorities for explaining how DNA evidence is extracted and analyzed. ${ }^{177}$ These two reports have also been referenced for their explanations of statistical calculations as to the significance of a DNA match. ${ }^{178}$

174 There exists much legal academic literature discussing stakeholders' engagement with the six forensic science NAS reports. The authors undertook a review of each, and found 278 references for DNA Technology in Forensic Science (1992), 206 for The Evaluation of Forensic DNA Evidence (1996), 82 for The Polygraph and Lie Detection (2003), 68 for Forensic Analysis: Weighing Bullet Lead Evidence (2004), 34 for Ballistic Imaging (2008), and 391 for Strengthening Forensic Science in the United States: A Path Forward (2009).

175 See, supra, at page 13.

176 United States v. Berry, 624 F. 3d 1031, 1040 (9th Cir. 2010).

177 See e.g., Harmon v. State, 908 P. $2 d 434$ (Alaska Ct. App. 1995); People v. Soto, 21 Cal. 4th 512 (Cal. 1999).

178 See, e.g., People v. Reeves, 91 Cal. App. 4th 14 (Cal. Ct. App. 2001); People v. Pike, 53 N.E. 3d 147 (Ill. App. Ct. 2016). 
This reliance on the authority of NAS reports to provide information about forensic science techniques suggests that courts see the NAS as a scientific authority, independent of parties to the trial process. To this end, the authors suggest that the NAS could maximize the impact of its reporting in this way. One suggestion for doing this is for the NAS to create a living document (reflecting that this information may change in line with the nature of scientific inquiry) on forensic science techniques. Such a document could include a definition of all examined forensic science techniques, information about methods of identification and analysis, and a summary of limitations. Through the NAS collating existing forensic science definitions, legal actors benefit from a single-source material, which will provide an independent and authoritative referencing tool about forensic science techniques.

\section{ii. Targeting Trending Issues}

Part I highlighted that the selected reports have played a role in shaping conversations around trending issues in forensic science. For example, albeit resisted at first by the FBI, the CBLA Report ultimately kick-started changes in FBI practices, with the FBI recognizing action was needed. ${ }^{179}$ Further, Strengthening has evidently informed legal claims surrounding the reliability of several forensic disciplines. ${ }^{180}$ Noting this, it is suggested that the NAS continues to proactively identify issues in forensic science that are receiving increased stakeholder scrutiny. For example, the NAS could target reporting on what steps might follow the FBI's collaborative review of microscopic hair analysis, ${ }^{181}$ and/or further investigate trends in judicial decision-making as they relate to contentious forensic science evidence. In relation to the latter, for instance, there is a notable pattern in judicial decision-making with regards to the phraseology of expert testimony provided by firearm examiners. ${ }^{182}$ The authors suggest that the NAS could target reporting on these trending issues, in order to maximize their impact and assist stakeholders as they attempt to address uncertainties.

This proactive approach would be in line with the NAS' history of taking initiative to explore pressing issues, which contribute to enabling stakeholders to resolve uncertainty. This includes issues relating to criminal justice. For instance, the 1992 report-DNA Technology in Forensic Science - was born from a series of conversations between the FBI and the National Research Council in $1988 .{ }^{183}$ In the light that the FBI could not provide sufficient funds to investigate the DNA-related

179 See FBI National Press Office, supra note 33. Following the publication of the CBLA Report, the FBI conducted an internal review of CBLA practices and subsequently decided to discontinue CBLA.

180 A search for cases published between 2009 and 2018 that directly reference Strengthening was undertaken. This produced 218 results. These materials are on file with the authors.

181 The FBI last reported on the progress of its review of microscopic hair analysis in 2016. For more information, See, FBI Services, FBI/DOJ Microscopic Hair Comparison Analysis Review, https://www.fbi.gov/services/laboratory/scientific-analysis/fbidojmicroscopic-hair-comparison-analysis-review (last visited Feb. 28, 2019).

182 See, in general, Cooper \& Scanlon, supra note 134.

183 See archival material pertaining to DNA Technology in Forensic Science - materials are on file with the authors. 
issues, the NAS reached out to private and state bodies for funds. The NAS was successful in obtaining $\$ 310,000,{ }^{184}$ and initiated the study in January $1990 .{ }^{185}$

\section{iii. State Level Engagement}

Although the CBLA and Strengthening reports were commissioned by federal entities, their outcomes have been harnessed by state-based institutions to bring about change at state level. As discussed in Part I, Strengthening has been used by the Texan legislature to underpin broader criminal justice reforms, and also in North Carolina. State courts have also harnessed NAS reports to inform their decision making. Several state courts have used the CBLA Report to support decisions to overturn convictions, including the Court of Appeals of Maryland in Clemons v. State, ${ }^{186}$ and the Superior Court of New Jersey in State v. Behn. ${ }^{187}$ Again, this state-level impact is evident beyond these two reports. For instance, judges in California have used DNA Technology in Forensic Science and The Evaluation of Forensic DNA Evidence to inform their evolving approach to DNA evidence in criminal cases. ${ }^{188}$

This state-level traction suggests that federally commissioned and directed NAS reports can have a significant impact at state level. States can be considered more receptive and/or able to deliver reform. Reflecting on this, and the fact that the NAS' mandate does not expressly preclude them from receiving requests about and/or focusing on state-specific issues, the authors suggest the NAS could develop a state-specific portfolio, targeting issues of specific concern to individual states or groups of states.

\section{iv. Taking Forward National Efforts}

Albeit challenging, there have been national efforts to address concerns about forensic science. The National Commission for Forensic Science (NCFS), and the 2016 President's Council of Advisors on Science and Technology (PCAST) report emerged from observations set out in Strengthening. As explored in Part I, the NCFS was disbanded in 2017, and the 2016 PCAST report has had a critical response and somewhat nuanced impact. ${ }^{189}$ Some have considered this disappointing. For example, Judge Konzinski expressed his dissatisfaction following the PCAST report, showing disappointment at the "swiftness with which the U.S. Justice

184 Id.

185 MCKusick ET AL., supra note 3, at vii.

186 Clemons v. State, 329 Md. 339 (Md. 2006).

187 State v. Behn, 375 N.J.Super. 409 (N.J. Super. Ct. App. Div. 2005).

188 In California, the 1992 case of People v. Barney (8 Cal.App.4th 798 (Cal. Ct. App. 1992)) became the leading case for determining the admissibility of DNA evidence using the ceiling principle under the Kelly admissibility standard, with subsequent cases using Barney as a starting point whilst incorporating technological developments. For example, People v. Venegas (18 Cal.4th 47 (Cal. 1998)) confirmed the admissibility of the product rule of statistical calculations following the publication of The Evaluation of Forensic DNA Evidence (1996) and People v. Reeves (91 Cal.App.4th 14 (Cal. Ct. App. 2001)) further developed DNA case law by holding that the product rule can be used when the DNA is analyzed using the PCR method.

189 See, supra, at 16-18. 
Department and FBI rejected the report on... insubstantial grounds." ${ }^{190}$ Similarly, Professor Epstein's response to the dissolution of the NCFS demonstrates frustration at the limited impact of the body. ${ }^{191}$ However, the authors suggest that the NAS - as an independent body - could be the appropriate body to re-energize these efforts, building on the foundations laid by the NCFS and PCAST, and using its expertise in bringing together multi-stakeholders to advance existing ideas. ${ }^{192}$

\section{B. Sensitivity to the FRAMEWORKS Within Which Stakeholders OPERATE}

A key element to building on existing stakeholders' engagement effectively would be to do so in a way that is expressly sensitive to the frameworks that stakeholders operate within. A variety of stakeholders - ranging from the FBI and DOJ, to the courts and Congress - have engaged with the CBLA Report and Strengthening. In preparing and publishing its reports, the NAS demonstrates an appreciation for its audiences and an awareness of consequences for stakeholders beyond their commissioning bodies. The same can be said in relation to the other NAS forensic science reports. ${ }^{193}$ Part I demonstrates, however, that each stakeholder can be limited in their response by their own institutional frameworks and culture.

This point can be teased out across various examples, with individual stakeholders demonstrating particular concerns. Congress and the FBI are expressly cognizant of resource implications. Congressional committees have addressed funding and resource issues several times. For example, the House of Representatives Committee on Science and Technology has expressed concern about a congressional focus on funding for DNA evidence projects to the detriment of non-DNA evidence projects. ${ }^{194}$ The FBI justified its discontinuation of CBLA by considering "the costs of maintaining the equipment [and] the resources necessary to do the examination." ${ }^{195}$ Further, the FBI and DOJ are clearly placed in a difficult position when presented with reporting that undermines their institutional practices, particularly those that have been in use for a long time. Moreover, they both demonstrate a preference for remedying problems from the inside out. For example, following the publication of the CBLA Report, the FBI initiated an internal examination of the technique before discontinuing the practice in 2005 .

190 The Philip D. Reed Lecture Series Advisory Committee on Evidence Rules, Symposium on Forensic Expert Testimony, Daubert, and Rule 702, 86 Fordham L. Rev. 1463, 1492 (2018).

191 See Epstein, supra note 164.

192 The NAS has already used its position to bring together stakeholders in workshops to discuss specific issues. See, e.g., Frederick L. Oswald, Personnel Selection in the Pattern Evidence Domain of Forensic Science: Proceedings of a Workshop (2017).

193 For example. DNA Technology in Forensic Science and The Evaluation of Forensic DNA Evidence showed appreciation for the fact that their purpose was to address judicial concerns. DNA Technology in Forensic Science was designed to respond to "questions concerning DNA typing... in connection with some well-publicized criminal cases," and The Evaluation of Forensic DNA Evidence was commissioned as "a follow-up study" to this. See, McKusick ET AL., supra note 3, at vii; CROW ET AL., supra note 3, at vi.

194 Committee on Science and Technology House of Representatives, supra note 96, at 9.

195 See FBI National Press Office, supra note 43. 
Similarly, by creating the National Commission on Forensic Science within the DOJ, the DOJ was able to first look internally at its practices. Judicial decisionmaking, on the other hand, is naturally informed by the legal process vision i.e., guided by such concerns as the need finality, and to make decisions that give deference to institutional competences, such as the designated roles of judges, lawyers, and jurors. This is evidenced in decisions including Commonwealth $v$. Joyner, ${ }^{196}$ Commonwealth v. Fisher, ${ }^{197}$ and State v. Romero. ${ }^{198}$ The courts and their actors can also be hindered in interpreting forensic science reports due to a lack of in-house scientific expertise. ${ }^{199}$ Generally, all stakeholders are vulnerable to the political climate of the day too.

These observations are not surprising. They reflect the very nature of the functions that these stakeholders perform. Common to them all, however, is a concern about maintaining public confidence in the criminal justice system, as each of them play a role in that maintenance. The NAS reports - through reflecting progression in scientific thought and/or a new presentation of existing knowledgenaturally have the potential to destabilize public confidence. Indeed, stakeholders have expressly recognized this. ${ }^{200}$

With this in mind, the authors' final suggestion is that the NAS-building on its current practices-more expressly shapes its reporting to account for the concerns of its primary audiences. ${ }^{201}$ This is not a call for the NAS to change the substance of the messages it reports, but rather a suggestion that it takes action to acknowledge more expressly the concerns of its audience(s). For example, the NAS could, within its reports:

196 The petitioner in Commonwealth v. Joyner, 467 Mass. 176 (Mass. 2014) argued that the statistical significance of fingerprint evidence should be presented alongside a match, using Strengthening as evidence that fingerprint matches are often overstated. The Supreme Judicial Court of Massachusetts rejected this, as precedent demonstrates the long-standing admissibility of latent print evidence, leaving the weight of the evidence to be determined by the fact-finder.

197 In Commonwealth v. Fisher, 582 Pa. 276 (Pa. 2005), The Supreme Court of Pennsylvania held that the CBLA Report did not constitute new evidence, dismissing the petitioner's claim. They relied on two finality considerations for this: lack of evidence, and untimeliness of the petitioner's claim.

198 The Arizona Court of Appeals in State v. Romero, 236 Ariz. 451 (Ariz. Ct. App. 2014) dismissed the petitioner's claim using Strengthening that firearm evidence was not admissible under Rule 702 on the basis that the limitations of the evidence had been cross-examined and assessed by the jury at trial.

199 See, e.g., Edward Imwinkelried, Coming to Grips with Scientific Research in Daubert's Brave New World: The Courts'Need to Appreciate the Evidentiary Differences between Validity and Proficiency Studies, 61 BrooK L. Rev. 1247 (1995).

200 See, e.g., Jennifer E. Laurin, Criminal Law's Science Lag: How Criminal Justice Meets Changed Scientific Understanding, 93 Tex. L. Rev. 1751 (2015), which provides examples of stakeholders' responses to several events having the potential to undermine public confidence in forensic science relied upon by these bodies. It assesses stakeholders' responses in reducing the uncertainty caused, and their efforts to maintain public confidence in the criminal justice system's reliance on forensic science evidence.

201 It is evident that the NAS does take into account the context within which its reports are situated. One such example is in Strengthening where the report discussed issues with the Daubert framework. (EDwARDS ET AL, supra note 9, at 110). The authors suggest that these links should be made stronger. 


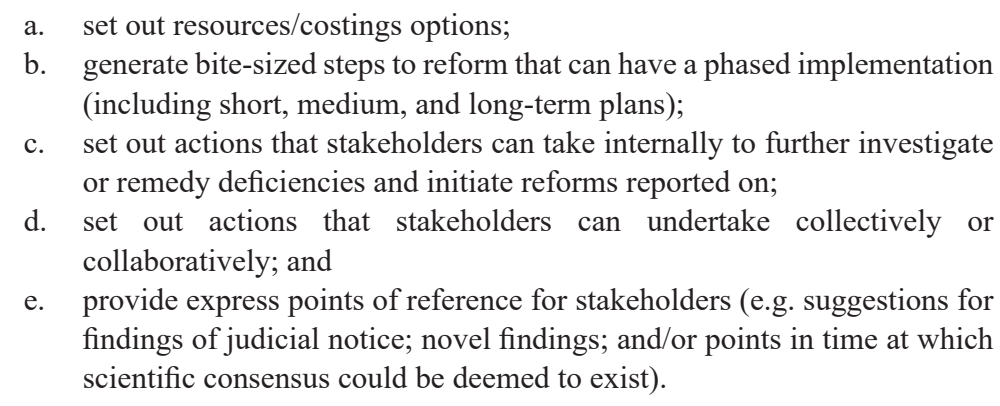

As part of this, the NAS can take a lead role in (1) facilitating cross-stakeholder collaboration; and (2) normalizing and explaining the nature of scientific method, progress, findings, and uncertainty.

The latter practice is, in particular, crucial. This is because many stakeholders are understandably nervous about taking actions that would undermine public confidence in the criminal justice system's actors, processes, and institutions (by, for example, declaring a long-time used forensic science identification method to be unreliable or, from a court's perspective, inadmissible). Law shapes the criminal justice system, and law is known for being skeptical about change, preferring to take approaches that achieve finality, predictability and procedural regularity. ${ }^{202}$ By contrast, science generally "embraces change." ${ }^{203}$ The products of the scientific method are widely understood to be provisional: hypotheses are routinely revised or abandoned and replaced by new dominant theories. This methodology "motivates more and more scientific study, and is thus vital to the scientific enterprise." 204 The NAS' forensic science reports embody this culture of science, reflecting a culture of collaboration and inquiry. ${ }^{205}$ As such, the NAS - through its reporting - can (continue to) play an important role in educating stakeholders and the wider public about the scientific method, including the normalcy of provisional findings and uncertainty. This is aligned with the NAS' role to provide independent, unbiased, and scientifically robust evidence that can inform sound public policy, ${ }^{206}$ and its mission to "encourage education and research... [and] increase public understanding in matters of science...." ."207

202 Sarah Lucy Cooper, Forensic Science Identification Evidence: Tensions Between Law and Science, 16 J. PHIL SCI. \& L. 1, 4 (2016).

203 Id.

204 Deborah M. Hussey Freeland, Speaking Science to Law, 25 Geo. Int'L Envtl. L. Rev. 289, 303 (2013).

205 For example, shortly following the publication of the NAS' first DNA report, DNA Technology in Forensic Science (1992), the NAS, in recognition of "a period of rapid progress," revisited several issues concerning DNA evidence in their follow-up report The Evaluation of Forensic DNA Evidence (1996). CROW ET AL., supra note 3, at vi.

206 National Academy of Sciences, Code of Conduct, http://www.nasonline.org/about-nas/ code-of-conduct.html (last visited Apr. 23, 2019).

207 National Academy of Sciences, supra note 10. 


\section{CONCLUSION}

The National Academy of Sciences is the United States' leading science and technology think-tank, with an active commitment to "provide scientific advice to the government whenever called upon." ${ }^{208}$ It has a mission to provide "independent, objective advice to the nation on matters related to science and technology", ${ }^{209}$ and to "encourage education and research [and] increase public understanding in matters of science ....". 110

Over the last 150 years, the NAS has generated a diverse and important portfolio of research, including six reports commenting on the status of forensic science evidence in the USA, namely DNA Technology in Forensic Science (1992), The Evaluation of Forensic DNA Evidence (1996), The Polygraph and Lie Detection (2003), Forensic Analysis: Weighing Bullet Lead Evidence (2004), Ballistic Imaging (2008), and Strengthening Forensic Science in the United States: A Path Forward (2009). These reports were fueled by growing concerns about particular forensic science disciplines (and specifically their application in legal proceedings). The response of stakeholders - including the FBI, Department of Justice, Congress, the judiciary, state legislatures, and the White House - to these reports has varied. Using the different experiences of two reports-Forensic Analysis: Weighing Bullet Lead Evidence (2004) and Strengthening Forensic Science in the United States: A Path Forward (2009) — as a vehicle, this article has suggested a template for how the NAS can strengthen the impact of its forensic science reporting, which will enable stakeholders to better harness the unique expertise of the NAS.

This two-part template first encourages the NAS to build on existing stakeholder engagement with its forensic science reporting. This includes developing referencing tools; targeting trending issues; engaging directly with states; and progressing existing national efforts. Second, the template encourages the NAS to be more expressly sensitive to the frameworks/cultures within which stakeholders operate. This may include reports setting out resources/costings options; bite-sized and phased reform plans; ideas for internal actions and external collaborations; and providing express points of reference. These suggestions will enable the NAS to take a lead role in (1) facilitating cross-stakeholder collaboration; and (2) normalizing and explaining the nature of scientific method, progress, findings, and uncertainty, so as to support stakeholders to maintain public confidence in the criminal justice system. This role aligns neatly with the NAS' unique history, function, and mission. 